
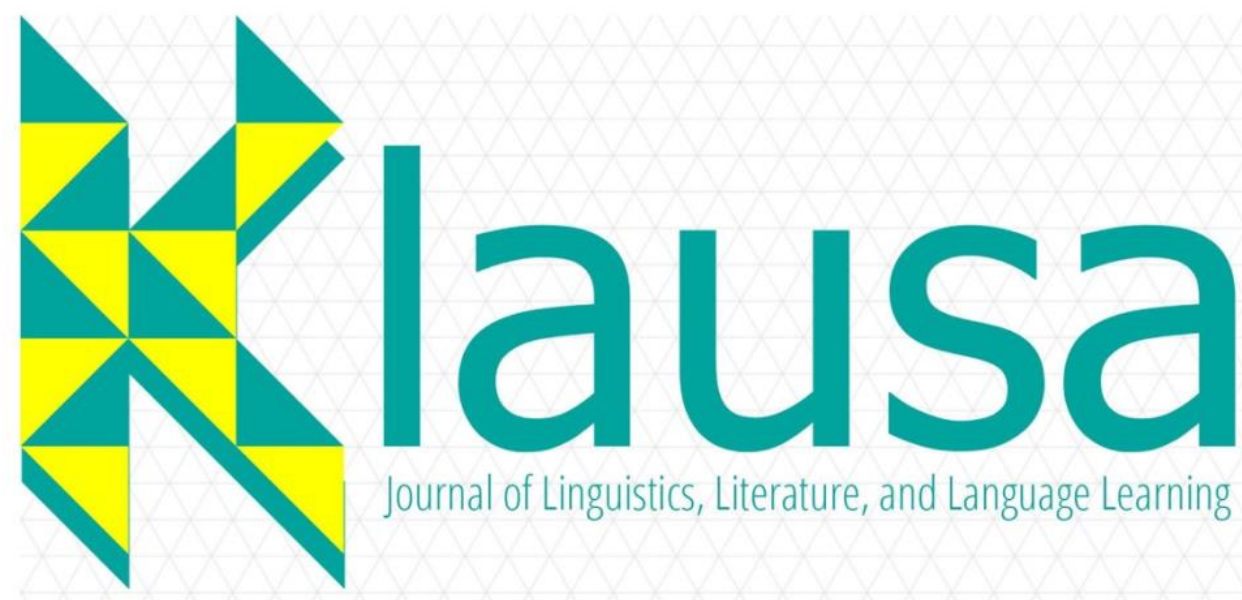

ISSN 2620-9527

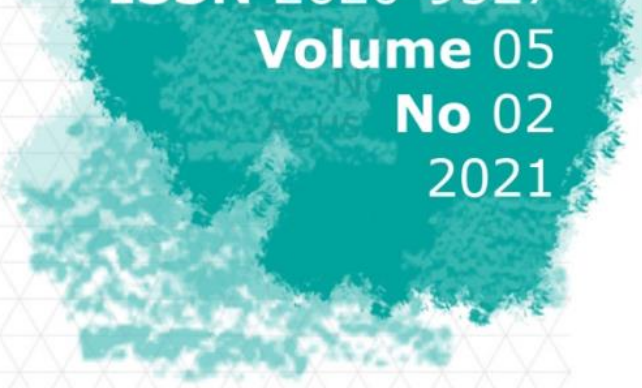

Journal of Linguistics, Literature, and Language Learning

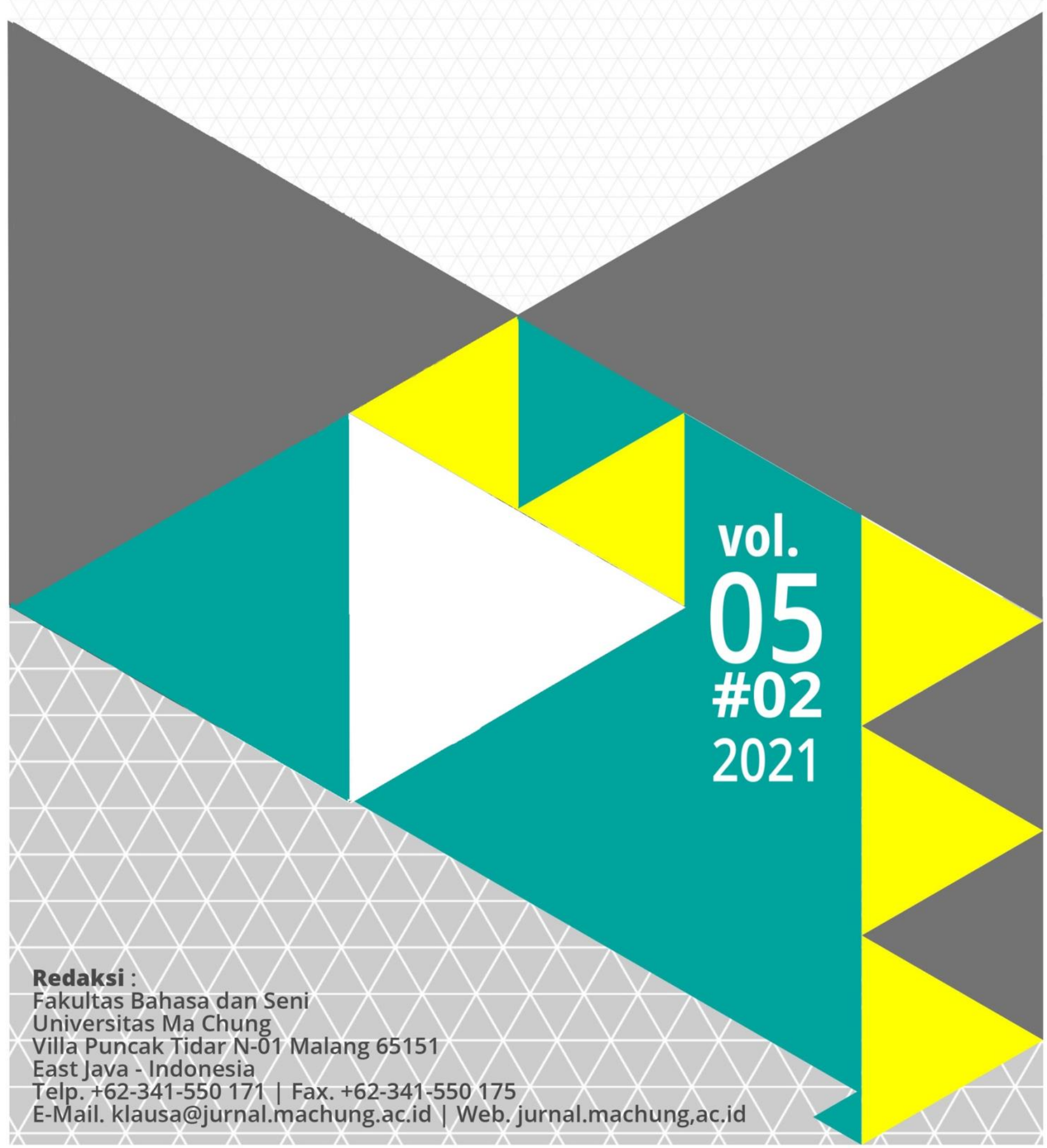


ISSN: $2301-4822(p)$

2620-9527 (e)

DOI:

\section{Kajian Linguistik, Pembelajaran}

Bahasa, dan Sastra

\section{Editorial Team}

Editor-in-Chief:Dr. Daniel Ginting

Journal Manager:Wawan Eko Yulianto, Ph.D.

Editors: Prof. Dr. Patrisius I. Djiwandono

Lilis Lestari Wilujeng, M.Hum.

Reviewers:F.X Dono Sunardi, M.A.

Dhatu Sitaresmi, MTCSOL.

Anggrah Diah Arlinda, MTCSOL.

Yohanna Nirmalasari, S.Pd., M.Pd.

Prof. A. Effendi Kadarisman, Ph.D.

Sisilia Halim, Ph.D.

Dr. Mundi Rahayu

Dr. Ross Wood

Dr. Leticia Araceli Salas Serrano

Publisher: Faculty of Language and Arts

Universitsas Ma Chung

Address: The Faculty of Language and Arts

$$
\begin{aligned}
& \text { Ma Chung University } \\
& \text { Villa Puncak Tidar N-01 (65151) } \\
& \text { Malang, East Java, Indonesia } \\
& \text { Email: jurnal.klausa@machung.ac.id }
\end{aligned}
$$

Frequency: Twice a year 


\section{CONTENTS}

FOREWORD

iii

SOLIDARITY IN THE TOURING NARRATIVE OF S.U.U.A.L (SCOOTER UIN ULUL ALBAB)

MALANG VESPA COMMUNITY: A CRITICAL DISCOURSE ANALYSIS APPROACH

Yunia Dewi Fathmawati ${ }^{1}$

THE ROLE OF PARENTAL GUIDANCE ON VOCABULARY ACHIEVEMENT IN AN INDONESIAN EFL ELEMENTARY EDUCATION SETTING

Christian Edison Bani ${ }^{1}$, Sahiruddin ${ }^{2}$, Ika Nurhayani ${ }^{3}$

MENELAAH POTENSI SASTRA PARIWISATA DI TELAGA SARANGAN

Ardi Wina Saputra ${ }^{1}$, Rustiati ${ }^{2}$

MAKNA KULTURAL DALAM LEKSIKON PERHIASAN PENGANTIN SUNDA PRIANGAN (KAJIAN ETNOLINGUISTIK)

Elda Mnemonica Rosadi ${ }^{1}$, Retty Isnendes ${ }^{2}$, Mahmud Fasya ${ }^{3}$

133

THE ENVIRONMENTAL ASPECTS OF ALEXANDRE DUMAS'

THE COUNT OF MONTE CRISTO

Gusti Ayu Made Suarniti ${ }^{1}$ 


\title{
SOLIDARITY IN THE TOURING NARRATIVE OF S.U.U.A.L (SCOOTER UIN ULUL ALBAB) MALANG VESPA COMMUNITY: A CRITICAL DISCOURSE ANALYSIS APPROACH
}

\author{
Yunia Dewi Fathmawati ${ }^{1}$ \\ ${ }^{1}$ Universitas Gadjah Mada, Indonesia, yuniadewif@mail.ugm.ac.id
}

\begin{abstract}
Vespa community is known for its solidarity value and S.U.U.A.L Malang is no exception. The application of this value can be observed from the activities or experiences by the group members. In this research, the touring experience of the community is taken as the data since during the trip, there are some inconvenient moments and unexpected accidents that happen. The concept of solidarity can be traced through how the group members face those moments. In this research, the data are divided into five categories based on the situation: natural obstacles, technical problems, resource limitations, the unexpected accident, and the inconvenient situation. To uncover the solidarity concept of the community, Critical Discourse Analysis (CDA) is applied to the narratives of three narrators which are the group members of S.U.U.A.L. The result shows that among five types of solidarity (cooperation, fairness, altruism, trustworthiness, and considerateness), there are two types that are found in the touring experiences by the group members, namely, fairness and altruism.
\end{abstract}

Key Terms: vespa community, touring, solidarity, Critical Discourse Analysis.

\section{INTRODUCTION}

For its vintage and unique shape and design, vespa charm succeeds in attracting many people. This Italian-based production type of scooter has diehard fans with fantastic numbers, therefore, no wonder that many of them subsequently gather and establish or join in vespa communities. Those who are the part of the community are not limited in gender, age, occupation, to the vespa's type and variety (antique, matic, ceper, gembel, etc.). Every single difference does not become a serious barrier among the 
scooterists (an epithet for vespa or scooter riders) to gather around as the community of vespa lovers.

The Vespa comunity everywhere commonly has some activities' agenda. It can be in periodic (weekly, monthly, and annually), as the agenda of kopi darat or kopdar (an agenda in which the members of the community gather in one place and do the lists of scheduled activity), or the impromptu ones as fundraising activities for the nation's catastrophe. Among those agenda, the one that attracts people's attention is touring activity. Vespa touring is an activity in which the scooterists ride their vespa in a group, commonly side by side and dominating the street. The riding is completed from one area to another. The destination can be a place, event, city, or even country at the most extreme level. Along the way, it is not often that the vespa rider group will catch everyone's eyes. The unique shape of the scooter, the attributes they bring on their vespa, and not to mention the scooterists' fashion styles that are sometimes eye-catching which make it so.

Further, the duration of the touring depends on how far the destination will be. Any kind of trouble, inconvenience, and sudden incident also has to be taken into consideration in deciding the day's duration of the touring. The inconvenience itself can appear in any form, it can be from nature, the scooter machine, to the vehicle legality issue. Yet, there are also many goodness that happen among them, that coming from the inside group or the people outside the group. To sum up, the bad and good things will always be faced by the vespa riders during their touring, it is how the group of scooterists can pass it together that define and even test their solidity as a community.

In Indonesia, vespa communities are considered as one of the oldest and the most member vespa communities in the world. According to (Herman, 2018) and (Arifin, 2019), the Indonesian vespa community places the second biggest one after Italy. (Khoirudin, 2013) states that the number of fans of this bee-body-like type of motorcycle in Indonesia has reached 40.000 . Compared to other comunities in the country, the vespa community is considered the biggest. They are spread from Sabang to Merauke and grouping in the level of province, city, and even institution. The bigger community contains any kind of vespa shape and type as its members, yet, they also form a smaller group with a particular type of vespa. For example, there are communities that are only specialized for matic scooterists, or, there are also small groups for the classic ones. Even so, they are still united under a "big umbrella" of the vespa community, regardless of the shape and the type of vespa.

S.U.U.A.L Malang is one of many institutional-based vespa communities. S.U.U.A.L is the abbreviation of Scooter UIN Ulul Albab, taken from the name institution, which is UIN (Universitas Islam Negeri) and its university principal, which is Ulul Albab. The community members are the scooterists who are students of Universitas Islam Negeri (UIN) Maulana Malik Ibrahim Malang. Established in 2013, S.U.U.A.L Malang are founded by several students of 2013 and 2014 from any faculty and major. Everyone is allowed to 
join in the community and they are not obliged to own a vespa. As long as they have similar interest in vespa or its machine, college students from any kind of institution are welcome there.

There are no particular requirements to be member of S.U.U.A.L Malang, they only have to come to the kopi darat activity that commonly is held every Tuesday. Further, they do not only stand on its own, the community is also affiliated with other campus communities as A.S.U (Asosiasi Scooterist UNISMA), BOSCAMM (Bolo Scooter Kampus Muhammadiyah Malang), and SCOOBI (Scooter Universitas Brawijaya) Malang, and also city-based community as Komunitas MALVES (Malang Vespa). It is not rare that the communities arrange a kopi darat activity in a big group, that commonly be held in public spots of Malang city. Therefore, the relationship of the community is not only kept well among the group members but also with other groups.

As also seen in any other community, relation and interaction between the group members are indeed important. In the vespa community itself, particularly in the community of S.U.U.A.L, the members' solidarity principle becomes the primary aspect that everyone notices. It is generally known that the members of the vespa community are considered loyal and solid compared to any other groups of people. The most obvious proof is as seen on the street. Most people must notice that every time vespa riders are passing by each other, either coincidentally or not, they often say greetings. They honk every vespa rider they meet, regardless if they know each other or not. It is their interest and hobby on vespa that makes them feel like knowing for years, as meeting the unknown brothers, and as brothers, caring is a must thing to do. This solidarity value is summed up by their mottos: "Semua Vespa Itu Bersaudara (translate: All Scooterists are Brothers) and "Satu Vespa Sejuta Saudara" (translate: One Vespa, A Million Brothers). This kind of solidarity and togetherness that makes the vespa community still exists until even now, even global technology has been massively evolved and somehow erases many things that are considered natural for humans, including human connection that day by day reduces in quality.

Theoretically, according to (Laitinen \& Pessi, 2014), group solidarity involves the group liability of joint debtors. The word 'solidarity' originally derives from Latin (Komter, 2005), which is obligatio in solidum. Émile Durkheim, a classics sociologist, adopts the word as a basic terminology in social sciences. He refers to the word as a readiness of emotional and normative motivation for mutual support. In addition, solidarity is also closely related to the slogan 'one for all and all for one' (Featherstone, 2012; Krunke et al., 2020; Van Hoyweghen \& Aarden, 2021). Commonly, the term solidarity is used to explain the concept of normal order and normative social integration in society or community and it is the opposite of chaos or conflict.

(Durkheim, 1984) defines solidarity as the feeling of trusting every member of a group. Once trust grows, friendship will be established. In addition, other behaviors such as being respectful, responsible for each other's well-being, and concerned with every 
group member's needs also will grow eventually. In line with Durkheim, (Johnson, 2008) also defines solidarity as a state that refers to a relationship between an individual and/or a group based on trust and similar emotional experience.

Further, as quoted by (Laitinen \& Pessi, 2014), a social philosopher Larry May mentions that the term 'solidarity' consists of five elements: 1) Conscious identification with the group, 2) Bonds of sentiment, 3) Common interests in the group's well-being, 4) Shared values and beliefs, and 5) Readiness to show moral support. The principal notion of solidarity is that individual well-being is as important as the group's and can not be separated from each other. To a great extent, May also adds that in this way, uniformity is an important aspect in solidarity. This can be found in the form of shared values and beliefs, or common history or living in the same area.

A German social philosopher, Andreas Wildt, as stated by (Laitinen \& Pessi, 2014), mentions that there are nine indicators which can show that someone performs an act of solidarity. The indicators are: 1) the presence of feeling sympathy and belonging together, 2) the action is partly pushed by altruism, 3) the action is considered as an act of helping in distress, 4 ) the actor considers the action as moral problem and injustice, 5) the actor considers her/himself obligated in helping others, 6) the disbelief feeling that the recipient has particular moral and emotional right to receive the special treatment, 7) the assumption that the recipient evaluates the distress in a similar way, 8) the actor assumes that the recipient is pushed to alleviate the distress and actively attempts to do so, and 9) the assumption of the possibility of analogous situations in which the recipient acts, has acted, or will act towards the actor.

Lindenberg (in (Laitinen \& Pessi, 2014) categorizes solidarity into five types. The first type is 'cooperation' which refers to a situation where common good is produced. The second type is 'fairness' or a situation of sharing. Next, the third type is 'altruism' which refers to helping situations in distress. The fourth type is 'trustworthiness' or a tempting situation in which disobeying contracts is possible. Finally, the last type is called 'considerateness' that refers to a situation in which things go awry and promises can not be fulfilled. This research will trace the solidarity value by referring the action and behavior to these theories mentioned.

As review of related literature, two researches are chosen. The first research was conducted by Agus Efendi, Andrik Purwasito, Bani Sudardi, \& Wakit Abdullah (2016) from Universitas Sebelas Maret Surakarta. It is published in KOMUNITAS (International Journal of Indonesian Society and Culture) volume 8 number 2. The research uses Critical Discourse Analysis as its approach and applies interviewing, observation, and content analysis as the techniques. This study is useful for the researcher to know about the data categorization. Further, the content analysis used by Efendi, et.al is also helpful since it elaborates about how text and context are related by analysing the units of sentences.

Another research that is also useful for the researcher is entitled "Reflection of Ideology: A Critical Discourse Analysis of Trump's Declaration Speech of Jerusalem as 
Capital City of Israel" by Widyo Andana Pradiptha (2020) from Universitas Jenderal Soedirman. The research focuses on how Donald Trump's speech contains political partiality on a particular conflicted country. The analysis applies Critical Discourse Analysis as the theory as well as method. Pradiptha's research is useful for the researcher since both studies puts attention on the spoken utterances. The research is inspiring particularly on how to collect the data and do the analysis towards the taken data. Both researches also contain ideologies even in the different aspect, Pradiptha with the political ideology while this research will point out on the socio-culture.

This research analyzes the solidarity philosophy found in the touring activity of the vespa community. The analysis will be done by tracing through from the narratives by S.U.U.A.L community members in terms of their experiences of touring, particularly from its inconvenient parts. The construction of ideology is reflected in the language pattern used by interviewee's narrative. Therefore, Critical Discourse Analysis is applied as the theory and method for achieving the research goal.

\section{RESEARCH METHOD}

\section{The Approach}

In conducting the research, a Critical Discourse Analysis (CDA) is applied. The critical approach is used in finding the realities that are contained in the existing report. As known, for it is used to communicate to one another (Muttaqin et al., 2019), a text is never neutral and always related to social contexts. This is what CDA believes, that any kind of text (written, spoken, or visual) should not be taken as a granted (Hussain, 2015). A text always carries the meanings that are intended to be delivered (Wahyudi, 2018), as well as value or ideology since text is the fruit of someone's thinking process. In line with Hussain, (Fairclough, 2001) also states that ideologies reside in texts. It means that within a text, the reader can uncover the ideologies contained since the forms and content of texts are produced from ideological processes and structures. Therefore, it is not possible to read off ideologies from texts.

As proposed by (Fairclough, 2001), the method of discourse analysis includes three dimensions. The first is description which is the stage that focuses on the text. The second dimension is interpretation. It is the stage in which the focus is on the text as the product of the process of production and as a resource in the process of interpretation. Lastly, the third dimension is explanation which focuses on the relationship between interaction and social context. Those three dimensions are described visually as below: 


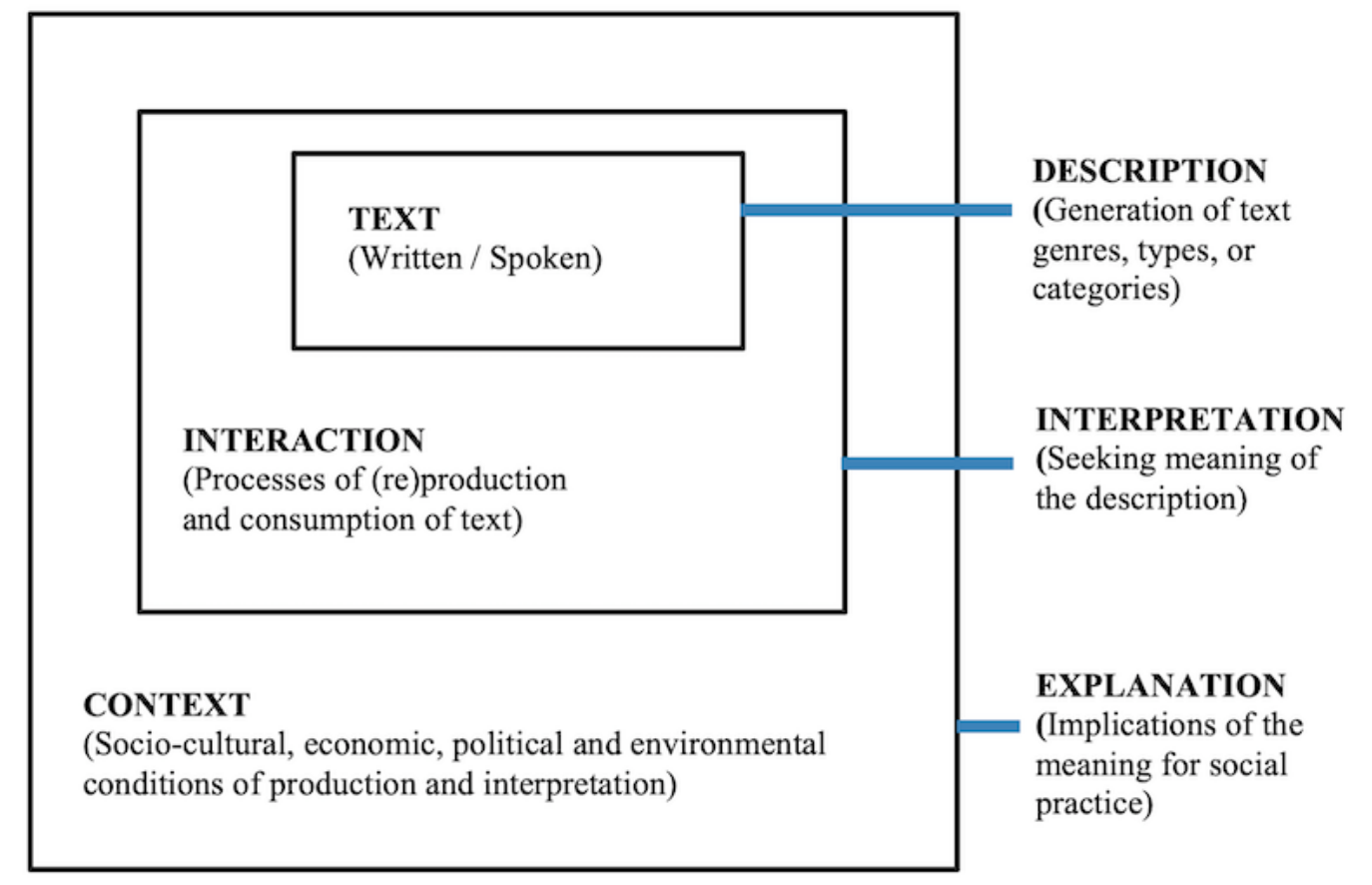

Fig 1. Fairclough's three-dimensional framework for discourse analysis

Fauzan (2014) summing up from Fairclough (1985) and Eriyanto (2001) characterizes CDA into several characteristics. The first character is action. Discourse is closely related with any kind of interaction. Discourse contains a particular purpose that is able to influence others. It is not produced as it is, instead, discourse exists for there is a particular interaction before it is produced (in (Hananto et al., 2020). Discourse is also conveyed consciously and mostly controlled. It is rarely delivered unconsciously and out of control (Ye \& Tang, 2016; Adams, 2017; Sujatmiko, 2020).

The second character is context. Discourse covers text and context. Text itself is described as any kind of language that can be in the form of written or spoken. Not only that, text is not merely language that can be read, it also can be listened and visibly seen. Therefore, text can be in the form of speech, music, pictures, images, and even sound effects. On the other hand, what by means of context is the situation and things that are outside the text. Context can influence the use of language, the participants, the situation in which the text is made, or the intended purpose.

Another characteristic is the historical aspect. Discourse can be well understood if the historical context is known. Understanding the discourse of a text will be fully obtained if we have the background of the historical context where and when the text was produced. Some examples of historical context are the socio-political situation in which the text is made, or the atmosphere where the text is produced.

The next character is called as power. Discourses that appear in the form of written text or spoken words are not natural and neutral. Instead, it shows a power 
struggle. Discourse can be seen as the media of controlling others. It is proven by the fact that many people or particular groups use discourse to make other people obey them.

Finally, the last character is ideology. CDA is applied to discover the ideology that exists behind language. Ideology becomes the main topic in the analysis of CDA. It is because text, conversation, and any other forms of discourse are used as ideological practice and reflection of particular ideologies.

In CDA, according to (Forchtner, 2021), narrative is considered similar to discourse. Narrative appears in eight forms, including ideology, framing, metaphor, identity, evaluation, conviction, erasure, and salience that has existed in a human's mind and then manifested linguistically, e.g. discourses. The context that is focused on when analysing a narrative in CDA is related with the theme, focusing on the 'what' of stories. In addition, themes in narratives (described as sense-making devices which articulate social realities and relationships) convey ideology.

Narrative itself, as defined by Roland Barthes (1975), is 'present at all times, in places, in all societies; indeed narrative starts with the very history of mankind; there is not, there has never been anywhere, any people without narrative'. Through narrative, humans arrange events causally, from beginning to end, making sense, and positioning themselves in time (Abbott, 2002). Further, it is through narrative that people are able to know, understand, and make sense of the social world. It is also through narrative that people can know each social identity. In sum, through narrative, identities can be presented, it is because the people and what happens in the world do not exist as it is. Otherwise, identities are meaningfully made through the narrative (in (Forchtner, 2021).

\section{The Methods}

In obtaining the data, the researcher uses narratives of S.U.U.A.L group members, particularly in relation with their touring experience. Three personal narratives are chosen as the material data. The personal narratives are delivered by three S.U.U.A.L group members: Hisyam (Narrator 1), Eno (Narrator 2), and Paijo (Narrator 3). At first, there are six narratives from six people that are obtained, yet, only three are chosen for those that represent well about the solidarity ideology that becomes the main focus in this research. The narratives are answered with the researcher's single question: "What is the most memorable and unforgettable touring experience you've ever had?". From that question, the narrators then tell the stories while the researcher takes notes and sometimes asks additional questions to make the narrators develop some parts of the narratives.

After the narratives are collected, the researcher then highlights some points that are related to the inconvenient moments during the touring experience and also the action and behaviors of the group members in handling the discomfortness. Subsequently, the points are grouped in tables with particular categorization. After that, 
the data are analyzed with solidarity theory as the theoretical basis. Finally, a conclusion based on the findings and discussion is drawn.

\section{FINDINGS AND DISCUSSION}

Vespa riders' touring experience tells a lot of stories, from the full of laughter to the sad ones. Each moment tests the group's solidarity: If they can pass the journey until the end, with noone left behind, then they can be considered as solid, and vice versa, if they can not make it until the end of the journey, then their solidarity is questionable. In this paper, the researcher tries to dig in the solidarity value in S.U.U.A.L vespa community through the members' vespa touring experience. Touring experience is chosen as the activity in discussing about the solidarity ideology since during the journey, there must be the ups and downs moment.

\section{The Discomfort Moments and the Solidaristic Action and Behaviors Followed}

Solidarity can be traced through any kind of inconvenient moment. This is as stated by (Laitinen \& Pessi, 2014). Solidarity is considered as a prosocial behavior in any kind of situation, including the action of helping and supporting those who are in need, doing one's part as a form of cooperation, being fair in sharing things, avoiding breaking the law to build a trust, and attempting to repair if violations have taken place. Further, solidaristic behavior requires a sacrifice, that someone's benefit will be surrendered for another's good sake or the whole group (Fetchenhauer et al., 2006).

In the touring experience of S.U.U.A.L Malang Vespa Community that is told by three members of the group, there are some inconvenient and troubled moments that happened during the journey. From the narrative telling process, the researcher has collected and highlighted some moments that are experienced by the members. The experiences are then categorized into five that are discussed in sub-subchapters.

\section{Natural Obstacles}

Nature becomes one of many obstacles in a journey of scooter touring. The unexpected weather often forces the rider to choose between two: Continuing the trip and dealing with anything that possibly happens along the journey, or, dismissing the trip for a while until the weather gets better. Many times, the group with fully-prepared supplies will choose the first option, while those with the limited ones prefer to choose the latter. There is one part of the narrative which indicates that nature becomes an obstacle. 
Table 1. Soldiarity in the face of Natural Obstacles

\begin{tabular}{|l|l|l|}
\hline \multicolumn{1}{|c|}{ The Narrator } & \multicolumn{1}{|c|}{ The Discomfort Moment } & \multicolumn{1}{c|}{$\begin{array}{c}\text { The Solidaristic Action and } \\
\text { Behavior }\end{array}$} \\
\hline Narrative 1 & $\begin{array}{l}\text { Waktu sampai di sekitar Pakisaji, } \\
\text { kita kehujanan dan akhirnya kita } \\
\text { berteduh sejenak. }\end{array}$ & $\begin{array}{l}\text { Karena yang bawa jas hujan cuma } \\
\text { satu orang saja, maka orang tersebut } \\
\text { juga ikut berhenti dan tidak memakai } \\
\text { jas hujannya }\end{array}$ \\
& $\begin{array}{l}\text { Translation: } \\
\text { When we arrived near Pakisaji, } \\
\text { decided to pull over for our ride. }\end{array}$ & $\begin{array}{l}\text { Since it was only one of us that } \\
\text { brought the raincoat, he decided to } \\
\text { pull over and waited for the rain to } \\
\text { stop with others. }\end{array}$ \\
\hline
\end{tabular}

From the findings above, it can be concluded that bad weather such as rain is considered discomfort for a scooter touring group. Not only can it cause the rider's body to not feel well, the slippery road and the limited visibility due to the raindrops, not to mention another disruption from other riders, will possibly cause the rider's focus getting disturbed (Black, 2019). Therefore, the members of S.U.U.A.L decided to pull over for a while. This decision is not unreasonable. If they continue the trip, the possibility that it can happen is that they can catch a cold, get in an accident in the street due to the track condition, or any other possible occurrence. The word that is chosen by the first narrator, which is "kehujanan" indicates that the members are helpless in facing the bad weather, so that they decide to avoid it. Further, the helplessness is followed by the action of them, which is pulling over, so as not to get wet.

As a form of solidaristic action and behavior, as told by the first narrator, Hisyam, even if there is one of the group members that brings a raincoat, he decides to not continue the journey and pulls over with others instead. He can make a choice to leave the rest of the members to be on time arriving at the destination, yet, he does not choose to do so. The action itself has portrayed a solidaristic action of oneself to the whole group since it costs one's benefit of another member, as stated by (Laitinen \& Pessi, 2014). This is emphasized by the chosen words by the narrator, which is "orang tersebut juga ikut berhenti". It portrays how the narrator confirms that what is done by that member is a form of solidarity, since the word "juga" signifies experiencing some things together with another.

\section{Technical Problems}

'Vespa' and 'getting stalled' are two unseparated terms. It has been an open secret that whenever a vespa touring is held, a stalled incident always happens on the street. Gufran (in (Suara Jelata, 2019) even claims that it is no fun when vespa does not get stalled 
during the touring. It means that, stalled vespa during the trip is a common thing that happens. The experiences of having a trouble scooter during the touring moment by S.U.U.A.L members are summed up in the table below.

Table 2. Solidarity in the Face of Technical Problems

\begin{tabular}{|c|c|c|}
\hline The Narrator & The Discomfort Moment & $\begin{array}{c}\text { The Solidaristic Action and } \\
\text { Behavior }\end{array}$ \\
\hline $\begin{array}{l}\text { Narrative } 1 \\
\text { (Narrator: Hisyam) }\end{array}$ & $\begin{array}{l}\text { (i) } \\
\text { Pas sampai di Trenggalek yang } \\
\text { banyak tanjakannya, ada salah satu } \\
\text { vespa (anggota kita) yang kampasnya } \\
\text { bau gosong.. } \\
\text { Translation: } \\
\text { Once I arrived in Trenggalek which } \\
\text { has many steep tracks, one of the } \\
\text { rider's vespa got trouble, the brake } \\
\text { pad was burnt. }\end{array}$ & $\begin{array}{l}\text { Lalu, kita berhenti. Berhentinya di } \\
\text { gunung. Nyari rumah gaada, tapi di } \\
\text { turunan kita lihat ada satu-satunya } \\
\text { warung dan akhirnya kita berhenti di } \\
\text { situ. Kampasnya didinginkan dulu } \\
\text { Translation: } \\
\text { We decided to stop. We stopped at } \\
\text { an uphill. We tried to find houses but } \\
\text { we could not find any. Yet, on a } \\
\text { downhill road, we saw one and only } \\
\text { little shop there. We finally dropped } \\
\text { in while waiting for the brake pad to } \\
\text { cool down. }\end{array}$ \\
\hline & $\begin{array}{l}\text { (ii) } \\
\text { Di perjalanan pulang, rombongan } \\
\text { nambah dua scooter, anggotanya jadi } \\
\text { tujuh vespa dan tiga belas orang. (Di } \\
\text { antara dua vespa yang baru } \\
\text { bergabung), ada satu vespa yang cc- } \\
\text { nya kecil (100 cc) sehingga jalannya } \\
\text { tidak bisa kencang. } \\
\text { Translation: } \\
\text { On our way back home, there were } \\
\text { two additional vespa with four group } \\
\text { members that joined in the touring. } \\
\text { There were thirteen members and } \\
\text { seven scooters in total. (Among those } \\
\text { two scooters), there was one that had } \\
\text { low machine capacity (100 cc), so that } \\
\text { it couldn't run fast. }\end{array}$ & $\begin{array}{l}\text { Alhasil, vespa lain harus } \\
\text { mengimbangi vespa tadi. } \\
\text { Translation: } \\
\text { As a consequence, another } \\
\text { scooterist had to lower their speed to } \\
\text { balance the } 100 \text { cc vespa. }\end{array}$ \\
\hline $\begin{array}{l}\text { Narrative } 2 \\
\text { (Narrator: Eno) }\end{array}$ & $\begin{array}{l}\text { Pas perjalanan touring ke Pantai } \\
\text { Ungapan, kampas kopling vespanya } \\
\text { Azfa (salah satu anggota S.U.U.A.L) } \\
\text { habis. }\end{array}$ & $\begin{array}{l}\text { Jalannya pas naik turun, Didorong } \\
\text { mulai habis subuh (jam 5-an) } \\
\text { sampai jam 8/9-an. Yang dorong } \\
\text { sekitar enam sampai tujuh orang. } \\
\text { Vespanya akhirnya dibenerin di } \\
\text { (lokasi) acara. Kita nggak nikmatin } \\
\text { acara malah benerin vespa. }\end{array}$ \\
\hline
\end{tabular}




\begin{tabular}{|c|c|c|}
\hline & $\begin{array}{l}\text { Translation: } \\
\text { On our journey to Pantai Ungapan, } \\
\text { Azfa's vespa got troubled, the } \\
\text { coupling brake pad was running out. }\end{array}$ & $\begin{array}{l}\text { Translation: } \\
\text { The vespa stopped on a hill. Then, } \\
\text { we pushed it from around } 5 \text { am to } \\
8 / 9 \text { am. There were six to seven } \\
\text { members who pushed it. The vespa } \\
\text { was finally repaired at the location of } \\
\text { the event. We did not enjoy the } \\
\text { show, instead, we repaired the } \\
\text { troubled vespa. }\end{array}$ \\
\hline $\begin{array}{l}\text { Narrative } 3 \\
\text { (Narrator: Paijo) }\end{array}$ & $\begin{array}{l}\text { Pas touring ke acara JSR X di Sentul, } \\
\text { Bogor, berangkat empat vespa, anak } \\
\text { delapan (jumlah rombongan). Kita } \\
\text { berangkat dari Malang lewat jalur } \\
\text { Batu. Pas sampe Pujon, vespanya } \\
\text { anak-anak trouble. } \\
\text { Translation: } \\
\text { On our way to an event of JSR in } \\
\text { Sentul, Bogor, there were four } \\
\text { scooters and eight members that rode } \\
\text { together. We departed from Malang } \\
\text { and passed through Batu. Once I } \\
\text { arrived in Pujon, some of the scooters } \\
\text { got troubled. }\end{array}$ & $\begin{array}{l}\text { Vespanya lalu didorong dari Batu } \\
\text { sampai ke bengkel di Jombang. }\end{array}$ \\
\hline
\end{tabular}

There are some technical problems that are mentioned by the three narrators. To summarize, the problems are related with the coupling brake pad that is either burning or running out, the low speed of the scooter due to the machine capacity, and another kind of not-detailed trouble. Those technical obstacles make the group trip delayed and can not follow the schedule the group has arranged. The trip duration will be longer than what they expected, the group can not arrive on time to the destination, and so forth.

If related with the theory of Wildt (in (Laitinen \& Pessi, 2014) mentioned earlier, the discomfort moments are considered as a situation of distress, since it costs one's benefit. This is the moment in which the solidity is tested as a group. The trouble is not experienced by the whole group members, it is only one or several people that experiences it. Those who do not have troubled scooter can easily decide to continue the trip and leave behind the troubled ones. Yet, based on the taken data above, the members of S.U.U.A.L group community do not do that, instead, they simultaneously find solutions together and solve it with their own way. These moments of discomfort can show how solid the group is through how the whole members act towards it.

Further, as mentioned in the previous chapter, the solidaristic action and behavior portrayed by the members of the group in encountering the difficulties is considered as the act of helping and supporting in situations of need (Stürmer et al., 2005; Decety et al., 
2016; Chit, 2020). This act is categorized as 'altruism' type. It is an act in which an individual (referred to as "Ego") helps others (referred to as "Alter") in distress. (Laitinen \& Pessi, 2014) state that what is considered as needs depend on the shared belief within the group. According to (Mardianinta, 2016), helping other group members become one of many prosocial acts (alongside cooperation, rescue, and generosity) in a vespa community.

From the data in the table above, there are some acts of helping that is done by the members of S.U.U.A.L group that can be highlighted from the narrative delivered by the three narrators. From the four taken data, the acts include: waiting for the scooterist's brake pad to cool down, balancing one of the scooters' speed, repairing the troubled scooter, and pushing the stalled vespa. Here are the further explanation.

From the first narrator (Hisyam), the utterances (in point (i)) "Lalu kita berhenti.....Kampasnya didinginkan dulu" are indicated as an act of solidarity. It is traced from the used word "kita" which is the pronoun for showing 'me and the others'. The sentences probably can not indicate more about the solidarity of the group, yet, since text represents an action or event, therefore, it can be concluded that the act that is portrayed from the text shows the solidarity itself. Particularly in this case, the act of the whole group members of S.U.U.A.L that join in the touring, which is "kita berhenti" is the indicator of a solidaristic act.

Further, the first narrator (in point (ii)) also mentions "Alhasil, vespa lain harus mengimbangi vespa tadi" in the second part of the narrative. As known, the word 'harus' or 'must/have to' that is used by the narrator is defined as a modal to express a command, an obligation, and so forth. The narrative, then, is understood that the group members have to lower their scooter's speed in order to balance the scooter's speed with low machine capacity. This act is done so that all of the touring members can arrive at the destination together, at a very similar time. This too emphasizes on the notion of "one for all, and all for one" as mentioned by (Laitinen \& Pessi, 2014) as the motto of solidarity.

From the second and third narrators (Eno and Paijo), it can be taken as a point that the technical obstacle S.U.U.A.L group members have to face during their touring is the stalled vespa. The only solution to face that obstacle is by pushing the scooter. This activity, further, can be easily done if more people involved in helping it. As mentioned earlier, the act of helping and supporting in situations of need is called as 'altruism' type of solidarity. Therefore, the act of the non-troubled scooter riders that help pushing the troubled ones in the touring is considered as a solidaristic act. The other scooterists have choice to leave the stalled scooter, yet, they prefer to choose helping him since his situation is in need, and as (Mardianinta, 2016) mentions, this act is a prosocial behavior that strengthen the solidarity in a vespa community. The narrative themselves can not explain more about the solidarity value in the narrative, yet, the action that is represented by the text has been enough to show it. 
Particularly for the narrative told by the second narrator, Eno, the researcher gives him a provoked question: "Kalian kan bisa sebenernya nelpon siapa gitu buat nyamperin si vespa mogok dan pemiliknya, terus kalian tinggal aja langsung ke pantai. Daripada buangbuang waktu di jalan kan?" (translate: You all actually can call anyone to come and help your troubled vespa's friend, then, just continue your trip, so that you can arrive at the destination on time. You will not waste your time if doing so, but, why do you wait for him instead?). The narrator then answers, "Emang bisa sih kayak gitu, tapi berarti kita egois dong ninggalin dulur (saudara) buat kepentingan pribadi? Lagian, inti dari touring ya kayak gini, bukan kapan nyampenya tapi gimana di perjalanannya" (translate: We may do that, but if we do it, it means that all of us act selfishly. We leave our friends for the sake of our ego. Anyways, the point of joining in a tour is not about arriving at the destination on time, but about how the trip is). In relation with the altruism type of solidarity, this additional data emphasizes more about it. From the action that is represented by the narrative, the rest of the group members lower their Ego (self) for the Alter (other). It is done to maintain their solidarity as a group.

\section{Resource Limitations}

(Laitinen \& Pessi, 2014) state that 'fairness' or 'situations of sharing' is a type of situation in which solidarity can be manifested. The Ego (the self) feels responsible in distributing burdens and beneficial acts in the form of giving everyone a fair amount of both burdens and benefits. Further, instead of maximizing oneself's benefits and minimizing her/his burdens, The Ego chooses to share it equally. Surely, the justice mentioned here depends on the shared value within the group.

In this sub-subchapter, three narratives from the first narrator (Hisyam) are chosen as the best data in explaining solidarity acts among the limitations the group has or faces. The limitations are in the form of facility, foods, and scooter's fuel. The data are summarized below.

Table 3. Solidarity in the Face of Resource Limitations

\begin{tabular}{|c|c|c|}
\hline The Narrator & The Discomfort Moment & $\begin{array}{c}\text { The Solidaristic Action and } \\
\text { Behavior }\end{array}$ \\
\hline $\begin{array}{l}\text { Narrative } 1 \\
\text { (Narrator: Hisyam) }\end{array}$ & $\begin{array}{l}\text { (i) } \\
\text { Di warung itu hanya ada satu kursi } \\
\text { sekitar dua meter-an dan satu meja } \\
\text { saja. } \\
\text { Translation: } \\
\text { In that little shop, there was only one } \\
\text { two-meters of length chair and one } \\
\text { table. }\end{array}$ & $\begin{array}{l}\text { Karena kita ber-sembilan orang, } \\
\text { maka kita duduk saling berhimpit di } \\
\text { situ. } \\
\text { Translation: } \\
\text { Since there were nine of us, therefore, } \\
\text { we sat crammed due to the limited } \\
\text { space on the chair. }\end{array}$ \\
\hline & $\begin{array}{l}\text { (ii) } \\
\text { Pas subuh, ada salah satu dari kami }\end{array}$ & Karena \\
\hline
\end{tabular}




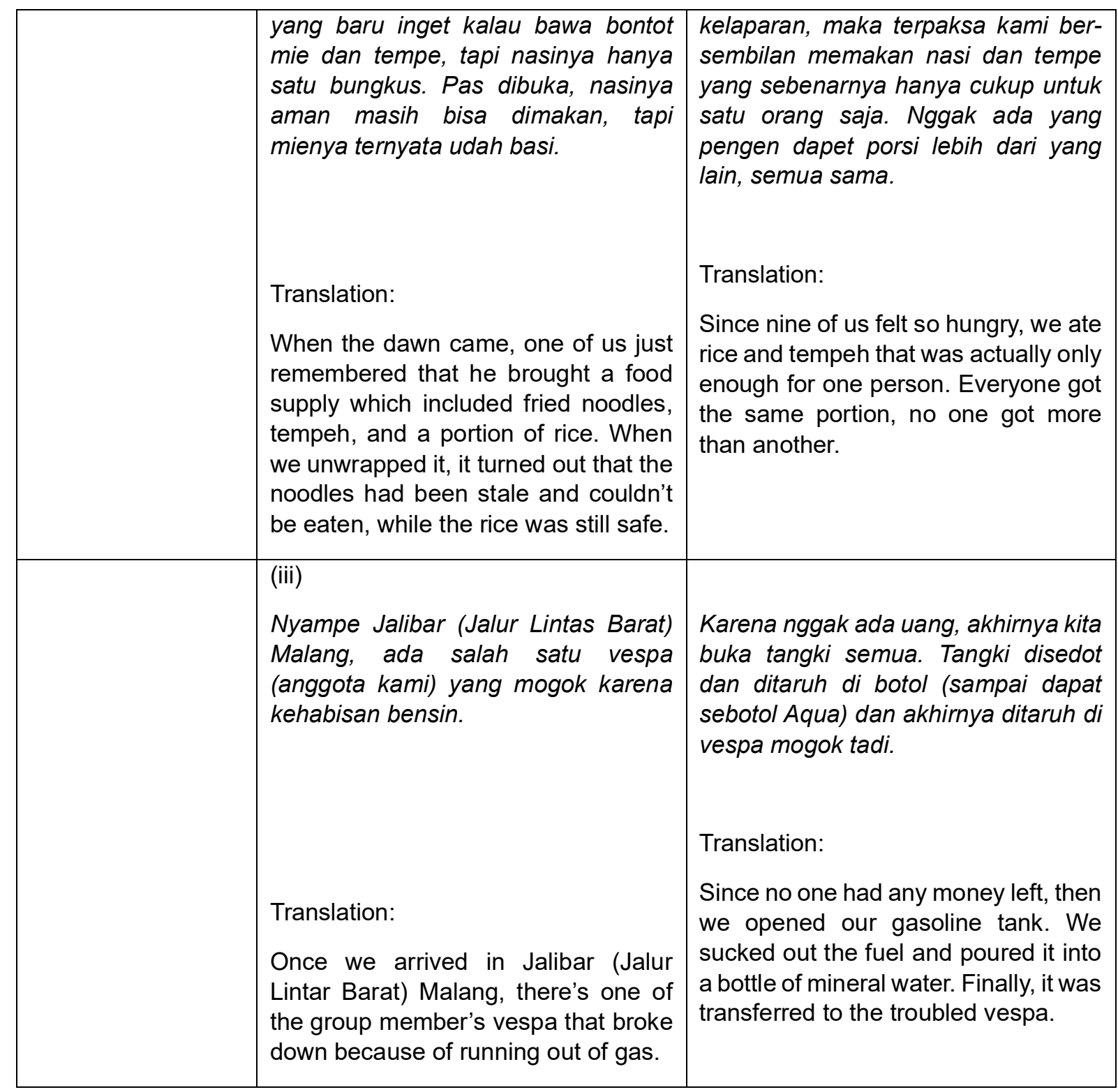

From the first narrative (in point (i)), it is mentioned that the nine group members of S.U.U.A.L who join in the touring finally find a place to rest and pull over due to the bad weather. In the little shop they drop in, there is only one chair. Instead of letting one or two people sit on the floor, they choose to share the chair. The part of the text that shows about the solidaristic action and behavior can be seen through the chosen words "Karena kita ber-sembilan..... maka kita....". 'Karena' and 'maka' are a pair of conjunctions in Bahasa Indonesia that indicate cause and effect. Hence, it can be concluded that from the sentence the narrator tells, the solidarity value can be seen in that particular act. Since there are nine group members in that situation, then, the effect is that everything has to be shared equally. This is emphasized by the chosen word 'kita' in the sentence that reflects togetherness.

Further, the second narrative (in point (ii)) shows foods as the limited resource for the touring group. Instead of eating it by himself, the one who brings the food chooses to share it with the others. In this case, it costs his own benefits. He actually can be full if 
eating it on his own, yet, the urgent situation pushes him to make himself not full, and even still get starved. This phenomenon is in line with what is stated by (Laitinen \& Pessi, 2014) that solidaristic behavior may require a sacrifice, or a cost to oneself for the benefit of another individual. This is because the act of solidarity is against hedonic behavior. It can be seen in the utterance "maka terpaksa kami ber-sembilan memakan nasi dan tempe yang sebenarnya hanya cukup untuk satu orang saja", particularly in the last sentence "yang sebenarnya hanya cukup untuk satu orang saja". The text shows that even if the touring group is in a condition in which food is very limited, they still manage it equally for the whole members.

In the third narrative (in point (iii)), the problem is about running out of fuel and money. The solidaristic behavior is clearly reflected from the action the text represents. It is "tangki disedot dan ditaruh di botol (sampai dapat sebotol Aqua) dan akhirnya ditaruh di vespa mogok tadi". The act of sharing goods itself is the reflection of a solidaristic act. This is categorized as 'fairness' type of solidarity. In this particular case, The Ego (the self) distributes the benefits they have, which is the fuel, to The Alter (the others) who are in need. Further, what is done by the members is actually a dangerous thing, considering that the fuel can possibly be swallowed through the body. The researcher asks a further question regarding to Hisyam statement: "Emang cara kayak gitu nggak bahaya ya, Mas?" (translate: Isn't it hazardous?). The narrator (Hisyam) then answers, "Bahaya atau nggak, selama kita bisa bareng terus, ya kenapa enggak?" (translate: Either it is hazardous or not, as long as we can be together, then, why not?). This point emphasizes that togetherness is the part of a solid group. This is in line with the statement of (Laitinen \& Pessi, 2014) that solidarity can be related to the principle of 'us together'.

The Unexpected Accident

Accident is the common thing that happens in the street, especially when it comes to a vehicle touring agenda. Even if the riders or drivers have managed themselves to beware and carefully \& mindfully driving in the street, the possibility of getting in an accident is still there. (Wicaksono et al., 2014) mention that there are several factors that cause the high number of accidents. The factors include traffic conditions in which it is the accumulation interaction of various characteristics of drivers, vehicles, road infrastructure, and environmental characteristics. The point is, there are many external causes that make a rider get into an accident in the street.

In addition, an accident is considered situation of distress since it costs one's benefit or fortune. (Laitinen \& Pessi, 2014) state that solidarity requires several attitudes or emotions including a sense of belonging, concern for the others' well-being, commitment to shared norms, valuing the social bonds in question or identification with the group. In relation to the unexpected accident that occurs in a group's touring experience, the situation involves one of a number of attitudes mentioned, which is concern for the others' well-being. It is because in an accident, usually there will be injuries, trauma, damage, and any other inconvenient things. If this is experienced by one 
or some members of the touring group, then the others are demanded to have concern for their well-being to build or maintain the group's solidarity.

Table 4. Solidarity in the Face of an Unexpected Accident

\begin{tabular}{|c|c|c|}
\hline The Narrator & The Discomfort Moment & $\begin{array}{c}\text { The Solidaristic Action and } \\
\text { Behavior }\end{array}$ \\
\hline $\begin{array}{l}\text { Narrative } 3 \\
\text { (Narrator: Paijo) }\end{array}$ & $\begin{array}{l}\text { Nyampe di jalur Salatiga-Pekalongan, } \\
\text { anak-anak (mengalami) kecelakaan: } \\
\text { Ekky kena jeglongan, jatuh. Terus } \\
\text { belakangnya ada Ucok yang kena } \\
\text { vespanya Ekky. Empat orang jatuh } \\
\text { semua. Dua vespa tadi hancur. Nggak } \\
\text { bisa buat jalan. Orang-orangnya luka. } \\
\text { Translation: } \\
\text { Once we arrived on the route of } \\
\text { Salatiga-Pekalongan, some of the } \\
\text { group members got into an accident: } \\
\text { Ekky and his vespa were trapped in a } \\
\text { deep hole and fell down. After him, } \\
\text { there was Ucok who crashed Ekky's } \\
\text { vespa. Four people fell off and two } \\
\text { scooters were broken and could not } \\
\text { work. The people on it were injured. }\end{array}$ & $\begin{array}{l}\text { Orang-orangnya luka dan akhirnya } \\
\text { dipinggirkan. Kita lihat ada warung } \\
\text { nganggur dan kemudian korban } \\
\text { dibawa semuanya ke tepi trotoar. } \\
\text { Salah satu anggota kemudian } \\
\text { meminta tolong grup Facebook vespa } \\
\text { Pekalongan untuk membantu } \\
\text { mereka. Salah satu rider yang sudah } \\
\text { duluan di depan akhirnya ditelpon dan } \\
\text { disuruh balik. } \\
\text { Translation: } \\
\text { Our friends were injured and we } \\
\text { carried them to the sideroad. We saw } \\
\text { an empty small shop and we brought } \\
\text { them all there. One of us then asked } \\
\text { for help from Pekalongan vespa } \\
\text { community through Facebook. Other } \\
\text { members that went before us were } \\
\text { asked to go back to the place where } \\
\text { the accident took place. }\end{array}$ \\
\hline
\end{tabular}

As a situation in distress, in an accident particularly, there will be parties that get lost. To be called solid, in a vespa touring group, those who are not involved in the accident are demanded to act towards those who get in an accident. The act can be in any form. Based on the data above, the solidaristic actions that are done by S.U.U.A.L members when an accident hitting one of them include carrying the injured to a safe place, asking for help from the outsiders or the parties outside the group, and asking the other members to go back to help them.

The solidaristic value that is found from the narrative above may be not able be traced from the text itself. Yet, since text represents an action, hence, the value can be seen from the action portrayed by the text. The acts that are done by the rest group members of S.U.U.A.L is considered as altruism type of solidarity since The Ego (the self) gives some help to The Alter (the others) that are in distress. In the case experienced by the touring group of S.U.U.A.L community, the members that get accident actually do not ask for help in a direct way, means that they do not speak any word to get helped. Nevertheless, the other members take an initiative to help them and do not leave them handling the situation by themselves. 
The Inconvenient Situation

A crisis oftentimes produces helplessness and a bad mood. As part of emotion, based on Zhu \& Thagard (2002), mood serves the function of responding to any kind of situation that is happening, whether it is harmful, threatening, or beneficial to the person's well-being. In many cases, it acts as the most reliable information about the situation and ourselves, and also provides the best way to respond towards both. When a good situation happens, oftentimes, it produces happiness, cheerfulness, cheeriness, and any other positive mood and energy. On the other hand, a bad situation or an inconvenient one sometimes results in a bad mood that can be in the form of sadness, sorrow, regret, grief, and many others.

In the touring experience by the members of S.U.U.A.L vespa community, the researcher takes one narrative told by the third narrator (Paijo) that shows a situation of discomfort that potentially creates a bad ambience. The situation occurs after an accident takes place and one of the group members gets injured. It is as written below.

\section{Table 5. Solidarity in the Face of Inconvenient Situations}

\begin{tabular}{|l|l|l|}
\hline \multicolumn{1}{|c|}{ The Narrator } & \multicolumn{1}{|c|}{ The Discomfort Moment } & \multicolumn{1}{c|}{$\begin{array}{c}\text { The Solidaristic Action and } \\
\text { Behavior }\end{array}$} \\
\hline Narrative 3 & $\begin{array}{l}\text { Pas di lokasi acara, Ekky (yang luka- } \\
\text { luka akibat kecelakaan) masuk lokasi } \\
\text { dan nggak ngapa-ngapain soalnya } \\
\text { kakinya masih luka. (Dia) nongkrong } \\
\text { di bawah pohon. }\end{array}$ & $\begin{array}{l}\text { Lalu anak-anak pada nyamperin } \\
\text { (Ekky). }\end{array}$ \\
& $\begin{array}{l}\text { Translation: } \\
\text { When we arrived at the destination, } \\
\text { Ekky (who got wounded) entered the } \\
\text { location and did nothing since his legs } \\
\text { were bloody injured. He ended up } \\
\text { sitting down under the tree and did not } \\
\text { follow the event schedule. }\end{array}$ & Translation: \\
& $\begin{array}{l}\text { Then, the rest of us sat next to him } \\
\text { and accompanied him. }\end{array}$ \\
\hline
\end{tabular}

From the data above, the bad ambience is caused by the accident that happened previously. As mentioned earlier, a bad situation possibly leads to a bad mood. It is portrayed from the narrative that shows how helpless the injured group member was after the accident, not to mention the distracted feelings and mental being of him. The helplessness is reflected from the chosen words "masuk lokasi dan nggak ngapa-ngapain soalnya kakinya masih luka". The first agenda of that injured member was probably to have fun in the event location, yet, due to the accident and its effect on him, he can not do anything but sit under the tree and watch the others enjoy the show. This situation then digs out how the rest of the members handle the situation as a solid group. 
The bad situation and mood are only experienced by one member of S.U.U.A.L, yet, the rest of the group members approach him as a form of solidarity. This is shown from the chosen words "lalu anak-anak pada nyamperin", especially from the word "pada" which means together. Based on (Laitinen \& Pessi, 2014), behavior is not enough for solidarity, since solidaristic actions require some attitudes or emotions including concern for others' well-being. In this case, the rest of group members may not ask in words about their concern towards the injured member, but, the action that they do says it all. Further, Andreas Wildt (1999, in (Laitinen \& Pessi, 2014) states that an action can be identified as an act of solidarity when the actor makes particular points. One of the points is the sympathy feeling when she/he does the act. The sympathy feeling probably is not delivered verbally, yet, it can be reflected from the action itself.

\section{CONCLUSION}

Uncovering the solidarity value in S.U.U.A.L vespa community can be traced through the narratives of the members' touring experiences. Results of the analysis show that the chosen words spoken by the narrators which reflects the text and context of the experience can indicate the solidaristic action and behavior of the group members towards some discomfort situation that happen during the touring. Discomfort situation is chosen as the data since it can reveal human's personalities, whether good or bad. In this research, the situations are divided into five. The categorization is made based on the data taken. From the collected data, it is found that among the five types of solidarity, only 'fairness' and 'altruism' are identified. Both are the only types that found as the result since in a touring experience, limitation and obstacles in any forms test how the group members share their benefits to others and how they release their Ego (self) in order to help the Alter (others). In addition, the solidaristic action and behavior owned by the group members joining in the touring are about how they continue the tradition of their predecessor, remembering that vespa community itself has been established since decades ago with the solidarity ideology as their basic shared belief in their hand. The experiences are the proof of how well they preserve the value as well as respect their seniors. For the future researcher, a research regarding to the solidarity ideology can still be dug in deeper. A historical approach would be an interesting theory to use.

\section{REFERENCES}

Adams, R. (2017, November 17). Michel Foucault: Discourse. Critical Legal Thinking. https://criticallegalthinking.com/2017/11/17/michel-foucault-discourse/

Arifin, R. (2019, April 5). Hanya Italia yang bisa kalahkan komunitas vespa di Indonesia. Oto Detik. https://oto.detik.com/komunitas-motor/d-4498248/hanya-italia-yangbisa-kalahkan-komunitas-vespa-di-indonesia 
Black, J. (2019, September 4). Safety: How to ride a motorcycle in the rain. https://www.rideapart.com/features/254439/safety-how-to-ride-a-motorcycle-inthe-rain/

Chit, Y. Z. (2020). Prosocial behaviours of members from student voluntary clubs in Sagaing University of Education. Indonesian Journal of Social and Environmental Issues (IJSEI), 1(2), 63-68. https://doi.org/10.47540/ijsei.v1i2.19

Decety, J., Bartal, I. B.-A., Uzefoysky, F., \& Knafo-Noam, A. (2016). Empathy as a driver of prosocial behaviour: Highly conserved neurobehavioural mechanisms across species. Philos Trans R Soc Lond B Biol Sci, 1686(20150077). https://doi.org/10.1098/rstb.2015.0077

Durkheim, E. (1984). The division of labor in society. Simon and Schuster.

Fairclough, N. (2001). Language and power.

Featherstone, D. (2012). Solidarity: Hidden histories and geographies of internationalism. Zed Books Ltd.

Fetchenhauer, D., Flache, A., Buunk, B., \& Lindenberg, S. (2006). Solidarity and prosocial behavior: An integration of sociological and psychological perspectives. https://doi.org/10.1007/0-387-28032-4

Forchtner, B. (2021). Introducing 'narrative in critical discourse studies.' Critical Discourse Studies, 18(3), 304-313. https://doi.org/10.1080/17405904.2020.1802765

Hananto, P., Hartanto, A., Pramadi, Y., Ubaidillah, U., \& Marzuki, A. A. (2020). Critical discourse analysis of community reports on Public Complaints Information Systems LAPOR! (lapor.go.id). Proceedings of the Proceedings of the 5th International Conference on Social and Political Sciences, ICSPS 2019, 12th November 2019, Jakarta, Indonesia. Proceedings of the 5th International Conference on Social and Political Sciences, ICSPS 2019, 12th November 2019, Jakarta, Indonesia, Jakarta, Indonesia. https://doi.org/10.4108/eai.12-112019.2293528

Herman. (2018, September 13). Indonesia miliki komunitas vespa terbesar kedua di dunia. https://www.beritasatu.com/otomotif/510319/indonesia-miliki-komunitasvespa-terbesar-kedua-di-dunia

Hussain, S. (2015). Critical discourse analysis: Demystifying the fuzziness. The International Journal Of Humanities \& Social Studies, 3, 242-249.

Johnson, D. P. (2008). Contemporary sociological theory: An integrated multi-level approach. Springer Science \& Business Media.

Khoirudin, A. (2013, March 22). Komunitas vespa Indonesia terbesar kedua setelah Italia. Otosia. https://www.otosia.com/berita/komunitas-vespa-indonesia-terbesarkedua-setelah-italia.html

Komter, A. E. (2005). Social solidarity and the gift. Cambridge University Press.

Krunke, H., Petersen, H., \& Manners, I. (2020). Transnational solidarity: Concept, challenges and opportunities. Cambridge University Press. 
Laitinen, A., \& Pessi, A. B. (2014). Solidarity: Theory and practice, an introduction. 30.

Mardianinta, W. (2016). Perilaku prososial pada scooterist vespa ekstrim di Semarang. 15.

Muttaqin, S., Sahiruddin, S., \& Rodliyah, I. N. (2019). Language variations in Madurese across regions and age groups: Looking at syntactic and lexical variations among regions and age groups. KLAUSA (Kajian Linguistik, Pembelajaran Bahasa, Dan Sastra), 3(01), 45-56. https://doi.org/10.33479/klausa.v3i01.193

Stürmer, S., Snyder, M., \& Omoto, A. (2005). Prosocial emotions and helping: The moderating role of group membership. Journal of Personality and Social Psychology, 88, 532-546. https://doi.org/10.1037/0022-3514.88.3.532

Suara Jelata. (2019, February 17). Touring vespa Sopa Sinjai: Tidak asyik jika motor tidak mogok. https://suarajelata.com/2019/02/17/touring-vespa-sopa-sinjai-tidakasyik-jika-motor-tidak-mogok/

Sujatmiko, S. (2020). Van Dijk modelling on critical discourse analysis (A study on Mata Najwa Program 'Gara-Gara Tagar' In Trans 7 in September 5th 2018). ELTICS: Journal of English Language Teaching and English Linguistics, 5(1). https://doi.org/10.31316/eltics.v5i1.533

Van Hoyweghen, I., \& Aarden, E. (2021). One for all, all for one? Containing the promise of solidarity in precision medicine. Critical Public Health, 0(0), 1-12. https://doi.org/10.1080/09581596.2021.1908958

Wahyudi, A. (2018). Interpretasi hermeneutika: Meneropong diskursus seni memahami melalui lensa filsafat modern dan postmodern. KLAUSA (Kajian Linguistik, Pembelajaran Bahasa, Dan Sastra), 2(02), 51-79. https://doi.org/10.33479/klausa.v2i02.150

Wicaksono, D., Fathurochman, R. A., Riyanto, B., \& Wicaksono, Y. (2014). Analisis kecelakaan lalu lintas (Studi kasus-Jalan Raya Ungaran-Bawen). Jurnal Karya Teknik Sipil, 3(2), 345-355.

Ye, D., \& Tang, L. (2016). Discourse control and power-Foucault's discourse control principle. https://doi.org/10.2991/iccsae-15.2016.31

Zhu, J., \& Thagard, P. (2002). Emotion and action. Philosophical Psychology, 15(1), 19-36. https://doi.org/10.1080/09515080120109397 